Research, part of a Special Feature on Realizing Water Transitions: The Role of Policy Entrepreneurs in Water Policy Change

\title{
Water Governance in Mexico: Political and Economic Aperatures and a Shifting State-Citizen Relationship
}

\author{
Margaret Wilder $^{1}$
}

\begin{abstract}
Since the adoption of dramatic national water policy reforms in 1992, Mexico's water governance paradigm has had time to mature. This article analyzes Mexico's experience with water policy transition, based on research in irrigation districts and river basin councils in the northwestern state of Sonora. I examine the trajectory of the water policy transition using the policy sciences framework set forth in the introductory article. The article argues that the transition to a "new culture of water" focused on the three principles of efficiency, decentralization, and sustainability has only minimally fulfilled its goal of establishing a new state-citizen relationship around water policy. Multiple and conflicting agendas are represented in the water policy, and a coherent governance strategy that is sustained over time and place has not been achieved. In particular, legal modifications to the national water law that emphasize integrated watershed planning and local participation were approved in 2004 but have never been formally implemented. Political fragmentation and changing of parties in power has contributed to the challenge of working towards a more democratic, participatory water policy over the last two decades. The article concludes with a critique of the policy sciences approach in the context of the Mexican case and that of other "developing" countries.
\end{abstract}

Key Words: ejidos; governance; irrigation districts; Mexico; river basin councils; Sonora; water policy

\section{INTRODUCTION}

For nearly 20 years, water policy has been a little noticed crucible in which to examine the advance of democratization and political opening in Mexico. In December 1992, Mexico adopted sweeping changes to its national water policy that presaged the possibility of a new state-citizen relationship. Mexico hosted the Fourth World Water Forum in 2006, and showcased its modernized water sector before thousands in attendance. The three key components of Mexico's strategy - marketization, decentralization, and sustainability - were embedded in a broader context of political opening and economic restructuring. The new policy envisioned a leaner and meaner role for the state while promising to institutionalize a new role for citizens as water users.

Decentralization of environmental policy is expected to result in increased local capacity in mature democracies, but the same expectation does not hold across the board in developing democracies where local capacity may be constrained by lack of financial and technical resources and entrenched political processes (Assetto et al. 2003). Multiple and often conflicting agendas were built into the water policy, which sought to make the water sector more efficient and sustainable while transferring the enormous financial burden of managing water systems to water users themselves (Wilder and Romero Lankao 2006). Mexico has emerged as what one World Bank observer called a successful new globalizer (Easter et al. 1998), while others see the national water reforms as either a mixed bag or an experiment that has failed in its fundamental objectives while further entrenching pre-existing inequalities (Barkin and Klooster 2006, Moreno 2006). The 2004 sustainability and decentralization modifications to the national water law have received very limited attention yet hold perhaps the most potential for transformative change if fully enacted. 
In this article, I advance two main arguments. First, the transition to a new culture of water in Mexico has only minimally and incompletely fulfilled its goal of establishing a new state-citizen relationship around water policy. In short, most of the democratic decentralization and sustainability reforms have been implemented on paper but not in practice. With the exception of irrigation district management by water users, other decentralization reforms such as municipalization of water management and integrated management by watershed councils have not been effectively implemented due to lack of resources, limited jurisdiction, and lack of fiscal authority. Reforms within Sonoran irrigation districts, for example, gave water users more autonomy and authority but led to economic vulnerability and loss of access to water for small producers, while Sonoran river basin councils have symbolic relevance but little impact or authority. Second, the 2004 legal modifications that would substantively commit Mexico to a more democratized water management paradigm have stalled out, due in part to the political aperture that has created a more fractured political and governance structure. Mexico's experiment with integrated water resources management and sustainable water policy making seems to be in pause mode, indicating a lack of commitment to full consolidation of the sustainability and democratization reforms.

\section{Political and economic apertures}

This analysis draws on the concept of aperture in two of its meanings to illuminate the transition in Mexico's water policy. In its common meaning, an aperture is an optical feature used to view an object, as through a camera. In this way, the water policy reforms serve as a particular lens through which to observe and interpret the democratic transition in Mexico. The water policy transition is a specific opening onto a set of political processes in transformation. An aperture is also a breaking open or opening up. Mexico's opening to admit new political parties and civil society actors to electoral and policy processes represents political aperture; in the same way, economic restructuring that admitted privatization, global markets, and trade agreements, represent economic aperture. In Spanish, political opening is referred to as $l a$ apertura política. This second sense bears some relationship to Kingdon's (1984) concept of political windows of opportunity for understanding policy change. This article employs the concept of aperture both as a specific lens via water policy onto processes of democratic transition and as the breaking open of broad political and economic processes themselves.

\section{Brief overview of policy sciences approach}

In seeking to understand why and how countries undertake water policy transitions, Huitema and Meijerink (Huitema and Meijerink 2010) take a policy sciences approach focused on the role of policy entrepreneurs, key change agents that create or take advantage of opportunities to shift the water management paradigm. The authors' point of departure is the processes that lead to water policy transition and the conditions of both change and stability resulting from the transition process. The policy sciences approach focuses on how new ideas are developed and adopted due to focusing events or shocks that galvanize willingness to adopt new policies; how coalitions advocating new water policies are built; how change agent entrepreneurs take advantage of windows of opportunity to initiate major changes and use multiple venues to implement policy change. This article makes periodic reference to the policy sciences approach, and in the conclusion, assesses its relevance for the Mexican transition.

\section{Methods}

I conducted research for this article between 1999 and 2008. Between 1999 and 2001,I interviewed more than 130 irrigation district managers, elected district officials, producer union representatives, private producers, and ejidatarios (small producers from ejido communities) in two irrigation districts (the Rio Yaqui Irrigation District-041 and the Altar-Pitiquito-Caborca Irrigation District-037) in the northwestern border state of Sonora, Mexico, and conducted follow-up fieldwork in 2005, 2006, and 2008. The sampling method used was purposive and non-random, appropriate for sampling of particular organizations and management behaviors (Blaikie 2000:5). Non-probabilistic sampling is appropriate to the study's objectives in order to identify water managers' and council participants' understanding of the role played by irrigation districts and river basin councils. The irrigation district fieldwork was funded by an Inter-American Foundation International Dissertation Fieldwork 
fellowship. In separate projects from 2004 to 2008, my research team interviewed approximately 40 municipal, state, and federal water managers regarding the river basin councils, and attended a limited number of river basin council meetings, as allowed. The river basin council research was part of broader research projects on water policy and climate change funded by the U.S. National Oceanic and Atmospheric Administration. ${ }^{[1]}$

\section{SALINAS-ZEDILLO ADMINISTRATIONS: 1988-2000}

Throughout the twentieth century until the late 1980s Mexico's water policy was highly centralized in a system best described as a limited authoritarian political system ruled by a powerful presidency (Assetto et al. 2003:254). The Secretary of Water Resources, headquartered in Mexico City, was responsible for operational and organizational decision-making about water at state and municipal levels, and within Mexico's 81 irrigation districts. Fiscal policy favored centralized control of government revenues, and localities were dependent upon Mexico City for fiscal subsidies. Decision-making was top-down and social participation in water policy was not formalized (Assetto et al. 2003, OECD 1998). A 1988 environmental law delegated authority for environmental matters not expressly within the federal jurisdiction (or otherwise limited by state law) to municipalities (Assetto et al. 2003, Mumme 2000). The year 1988 represented a major turning point as Mexico also began to shift toward a decentralized water management paradigm.

\section{Endogenous and exogenous pressures for transition}

By the late 1980s, Mexico's water infrastructure was in a shambles and the government had no resources to address its expensive, extensive needs. Mexico's irrigation infrastructure, responsible for over $80 \%$ of national water use, required staggering levels of investment to rehabilitate irrigation canals and channels, estimated at more than U.S.\$300 billion annually (Cummings et al. 1989:27). The federal government was subsidizing irrigation water use by $80 \%$, with irrigators contributing only $20 \%$ (CONAGUA 1994:26-27). The agriculture and water resources ministry had spent the previous three decades constructing expensive dams to open up new irrigated lands, but there was limited expenditure on maintenance of existing infrastructure (Cummings et al. 1989:27). Erosion was silting up irrigation canals, seawater salinization had damaged coastal aquifers, and faulty drainage crippled irrigation systems; half of the irrigation supply never reached cultivated fields due to leaks and runoffs (Yates 1981, Cummings et al. 1989, Buras 1996).

Apart from troubles in the water sector, Mexico was experiencing exogenous economic shocks. In 1982, the peso devaluation set off a chain reaction of defaults on international debts across Latin America. The 1985 earthquake, the 1986 oil shock, and the 1987 stock market crash sent reverberations throughout Mexico's government and business classes, and the resulting decline in real per capita income during the 1980s was as large as that of the Great Depression (Gould 1996). The new president, Miguel de la Madrid (1982-1988), inherited the worst economic crisis in the country's history (Gould 1996:23). By 1985, Mexico was forced to look for international assistance to restructure its debt, resulting in a U.S.\$12 billion International Monetary Fund rescue package (Gates 1988:299). The economic crisis was a focusing event for Mexico.

\section{Economic and political apertures}

As a result of the focusing event of the faltering Mexican economy, a new advocacy coalition began to take shape among the movers and shakers of the country (Sabatier 1993). A consensus emerged that the free market was the only way for the domestic economy to become viable in the world (ValdésUgalde 1996:59). In 1986, Mexico reversed its longstanding resistance to participating in international treaties and signed on to the General Agreement on Tariffs and Trade (later the World Trade Organization). Late in his term (1987), President de la Madrid led representatives of the labor, business, and farming sectors in the first of a series of new economic initiatives that were subsequently taken up by President Carlos Salinas after his 1988 election. The two measures, jointly referred to as the Pacto (pact), were designed to combine fiscal monetary restraint with structural reforms and an incomes policy (i.e., controls on wages and prices). From the late 1980s onward, opposition political parties from both the left and the right gained gubernatorial, legislative, and mayoral seats at state 
and local levels in unprecedented numbers (Dresser 1998). The process of alternancia-or changing political parties-presented new possibilities and challenges for the way water management would be carried out.

\section{Civil society actors}

Political aperture was reflected not only in the unprecedented changing - or alternancia - of political parties, but also in the emergence of new mobilizations of civil society during the 1990s. A 2000 Christian Science Monitor article on people power refers to a wave of citizen participation that is transforming Mexico, and to a new zeal for the possibilities of self-government (LaFranchi 2000). In 1994, the Alianza Cívica (Civic Alliance) emerged from an alliance of 300 non-governmental organizations as a very important democracy watchdog organization. Alianza Cívica's first major achievement was national election monitoring in 1994 (Santa-Cruz 2007). The unexpected uprising of the Zapatista movement in the southern state of Chiapas on 1 January 1994, the same day that the North American Free Trade Agreement (NAFTA) took effect, was the most dramatic sign of public mobilization to demand economic and environmental rights under the shift to neoliberalism (Harvey 1996). The growth of social movements in that decade was part of the broader political aperture reshaping water politics in Mexico. In 1990, the Nahuas indigenous people of the Upper Balsas region of Guerrero mobilized against a large-scale hydroelectric dam (the San Juan Tetelcingo) (Hindley 1999). Neighborhood residents in Mexico City took to the streets to resist privatization of municipal water services (Castro 2006). The Border Environment Cooperation Commission, created from the NAFTA environmental side agreement, institutionalized public consultation processes in a way not seen before, and environmental activism across the border region expanded (Lemos and Luna 1999, Liverman and Merideth 2002). Mexican citizens were demanding accountability and emerging as significant actors in the environmental policy arena.

\section{NAFTA and neoliberal restructuring}

The centerpiece of Mexico's economic strategy was the North American Free Trade Agreement, an agreement that took effect on 1 January 1994 among
Canada, the United States, and Mexico to phase out tariff protections and import quotas over a 15-year period. To much less fanfare, over the next 12 years Mexico entered into free trade agreements with multiple trade partners, including Israel, Chile, the European Union, Japan, and the Central American nations. In order to participate in NAFTA, Mexico was under pressure to modernize its water policy framework and water systems. Given the critical state of the water infrastructure, it became necessary to establish a new water resources policy that would increase industrial and agricultural productivity, ensure conservation, preserve water quality, and address supply and maintenance issues. NAFTA and the other free trade agreements intensified water use by stimulating industrial productivity and refocusing Mexican producers on high-value agricultural exports. The agreements forced smallscale Mexican producers to become more efficient and competitive or to abandon production and transfer land and water resources to private producers and corporate entities (Nadal 2002, Luers et al. 2005, Wilder and Whiteford 2006).

Subsecretary of agriculture Luís Tellez argued that the 1992 promulgation of the Article 27 constitutional reforms (that fostered private land titles and promoted land sales for communal properties or ejidos) and the adoption of a new Agrarian Law made it unthinkable for Mexico to continue with its outmoded 20-year-old Law of Federal Waters, which was not responsive to the country's modernization program. A new water law was needed that would facilitate increased user participation, authorize more legal security over the rights to use and exploit water, induce more efficient water use through conservation, and permit better administration of water toward the goal of integral, sustainable development (Tellez 1993:104).

\section{2 legal reforms (water, ejidos, forestry)}

Water policy was one of three sweeping areas of liberalized environmental policy reform that Mexico initiated in 1992. Neoliberal reforms to land tenure regulations for agricultural ejidos (smallscale communal farms) under Article 27 of the Constitution allowed ejido farmers to have a title to their farm parcel and to legally rent or sell the parcel (Cornelius 1992). Titles were conveyed to ejido farmers via a process of certification; once they had title to their parcels, ejido farmers could also use the land as collateral for credit and borrowing. Mexico 
liberalized its national forestry law in 1992, creating challenges for newly parcelized ejido communities that traditionally manage much of the forest land (Klooster 2003). The third major area of reform was to national water policy.

Mexico became an early adopter of a full slate of transformations in water policy that were promoted and partially financed by the World Bank and which centered around the principles of marketization, decentralization, and sustainability. The ultimate goal was expressly a new culture of water (President Salinas, cited in Tellez 1993:105). Luís Tellez, an Institutionalized Revolution Party (PRI) stalwart and a Massachusetts Institute of Technology (MIT)trained $\mathrm{PhD}$ in economics, was one of the principal Salinas technocrats responsible for the water modernization strategy.

Mexico's transition at the end of 1992 dovetailed with the 1992 Earth Summit in Rio de Janeiro. The Dublin Principles that same year called for understanding water as an economic good in order to maximize efficiency and promote conservation. Privatization of water services was held up as a desirable alternative to traditional state control which was seen as overly centralized, wasteful, out of touch with local realities, and inflexible. The new policies institutionalized a participatory role for local government, water user sectors and citizens in decision-making about water (Gleick et al. 2002, Blatter and Ingram 2001, Conca 2006, Varady et al. 2008). Mexico, following in the footsteps of Chile, emerged as a leader among developing countries that were turning to market-oriented, decentralized models for water management, including Brazil, Argentina, Peru, and Colombia in Latin America, and other developing countries (Easter et al. 1998, Hinchcliffe et al. 1999, Bauer 2004, Conca 2006, Lemos 2008).

Under the raft of influences detailed above, the Salinas administration (1988-1994) undertook a wholesale modernization and decentralization of water management. In February 1989, the National Water Commission (CONAGUA) was established as an independent agency attached to the Ministry of Agriculture and Water Resources. CONAGUA was the sole authority at the federal level to deal with water issues, and its primary responsibilities included designing water policy; formulating the national water program; developing potable and sewage water systems and treatment; constructing, operating, and maintaining dams and irrigation systems; expediting titles of concession, and developing a public registry of water rights (Ley de Aguas Nacionales, Article 8, 1992). ${ }^{[2]}$

Mexico's water governance paradigm included the major features prescribed by the World Bank and the Inter-American Development Bank, including the establishment of a public registry of water rights to provide secure water rights; the establishment of formal markets for trading water surpluses; the initiation of full-cost recovery water pricing and elimination of subsidies; the transference of irrigation district management to water user associations; the municipal and state management of urban water and sanitation services; the allowance of private sector management of water services via government concession; and an integrated water resources management that institutionalized local participation through the creation of a network of major river basin councils (consejos de cuenca). CONAGUA, as the federal water management agency, assumed a policy making and oversight role, leaving most daily operations and decision-making to municipal and state water managers and irrigation districts while retaining key strategic functions.

The scholarship on Mexico's water transition has focused on decentralization, privatization, and irrigation management (Torregrosa 1995, Palacios 1997, 2000, Whiteford and Melville 2002, Perez Prado 2003, Barkin and Klooster 2006, Wilder and Romero Lankao 2006, Pineda Pablos 1999, 2004, 2006, Pineda Pablos et al. 2007a, b), and on the implications of water reform for urban areas and for rural-urban trade-offs (Castro 2006, Moreno 2006). Most of these assessments are pessimistic about the real outcomes of the water policy transition and remain cynical about the likelihood of transformative democratic change in the water sector.

\section{Key change agent: Environment Minister Carabias}

The 1992 reforms were carried out by modernizing technocrats like Tellez within the Salinas administration. But environmental aspects of water management gained more prominence in the two successive administrations due to a major administrative change and the environmentalists at the helm. Following Salinas, Ernesto Zedillo was the PRI candidate elected to the presidency for the 1994-2000 term after the assassination of the original PRI nominee, Luís Donaldo Colosio. 
Zedillo created a new environment ministryMinistry of Environment, Natural Resources and Fisheries (SEMARNAP, later changed to Ministry of the Environment and Natural Resources (SEMARNAT) to reflect the movement of fisheries out of the agency). He appointed a respected environmentalist and academic, Julia Carabias Lillo, to head it. Carabias holds a master of science degree from Mexico's National Autonomous University (UNAM) and serves on the UNAM faculty in Mexico City. Carabias remains a very prominent voice for sustainable water and environmental policy in Mexico, and is the winner of both the 2005 United Nations Environmental Programme's Champions of the Earth award and the Cosmos 2004 International Prize. She served as the chair of the science and technology advisory panel of the Global Environment Facility (20022006). Carabias is the lead author of an important volume on water, environmental sustainability, and society (Carabias and Landa 2005).

During her tenure as Environment Minister, Carabias engineered the transfer of CONAGUA from the agriculture ministry to SEMARNAP. In the parlance of policy sciences, this was an important instance of achieving policy shifts via venue manipulation (Baumgartner and Jones 1991). Carabias was a policy entrepreneur interested in wresting water management away from the controlling grasp of the agriculture agency and transforming it into an agency focused on water conservation. According to Carabias, this change portended a broader turn - away from agricultural productivity and towards environmental sustainability as a principal focus of Mexico's changing water governance paradigm (interview, 18 January 2008).

"Everything was done that could be done under the 1992 National Water Law (LAN) - increased social participation and decentralization... The 1992 LAN represented a major advance (over the previous water law) in terms of the principles expressed, and those principles were ultimately concretized in the LAN of 2004, due to moving water administration to the environment agency SEMARNAT. Between 1992 and 2004, the major change was to incorporate a sustainability vision. Without that, the sustainability ethic might never have occurred" (interview, 18 January 2008).

Carabias's administration of SEMARNAT achieved some of the principal goals of the national water law, including the transference of irrigation districts to water user associations and the formal establishment of the river basin councils to take on integrated water resources management. An Organisation for Economic Co-operation and Development (OECD) environmental performance review of Mexico (1998) concurred with this assessment of the strong environmental achievements of SEMARNAT during this period. ${ }^{[3]}$ On the other hand, the change in venue for CONAGUA via its transfer to the Environment Ministry ran the risk of the tail wagging the dog given that CONAGUA's budget was 10 times larger than that of SEMARNAP and its related agencies (the national ecology institute and the federal environmental enforcement agency). ${ }^{[4]}$ When the decentralization program transferred to National Action Party administration in 2000 at the end of the Zedillo tenure, the vision and gains of the original eight years of the water reform program came under scrutiny, and additional modifications were pursued, as discussed in the next section.

\section{FOX AND CALDERON ADMINISTRATIONS: 2000-2008}

\section{The 2004 modification of the National Water Law}

The election of Vicente Fox Quesada as president of Mexico on 2 July 2000 heralded a new era in Mexican politics, the election of an opposition candidate to the presidency after a 71-year one party reign by the Institutionalized Revolution Party. Mexico proved to itself and the world that it was a democratic nation where opposition party candidates could be elected in a fair, non-violent process (Otero 2004, Preston and Dillon 2004). Fox's election was a culmination of 12 years of prior political opening, evidenced by very credible presidential runs by opposition candidates and increasing gubernatorial, senatorial, and congressional delegate seats won by opposition parties (Cornelius et al. 1999).

The initial elation soon dissipated due to Fox's inability to carry out the major promises on which he was elected, including fiscal reform, anticorruption policies, and comprehensive immigration reform in the United States. Fox appointed Victor Lichtinger, a high-profile environmental economist and former executive director of the trilateral (Canada/Mexico/United States) North American Commission on Environmental Cooperation as his 
environment minister. Lichtinger was a favorite of environmentalist groups and continued pushing Mexico's water policy towards a decentralized management structure, emphasizing the need for sustainable use of water resources while underscoring the importance of the private sector and markets to fix Mexico's water infrastructure. Lichtinger positioned himself as a crusader against corruption within the environmental bureaucracy and worked with Mexico's environmental enforcement agency to rein in corruption, especially at the state level. Due to the threat he posed to established interests, and despite the outcry of the environmental community, Fox fired Lichtinger midway through his term (September 2003) and replaced him with an engineer who had no environmental credentials. As one observer wryly noted: Fox wanted experts, but he needed politicians (Vera 2003).

\section{Discussion of $2004 \mathrm{LAN}$ reform and regulations}

The 2004 sustainability and decentralization LAN modifications resulted from a course on the environment requested by senators in the period just after Carabias left office (Carabias interview 18 January 2008). The expert consultations organized before the senate resulted in a proposal to modify the LAN. In April 2003, the Senate's Water Resources Commission, headed by PRI Senator Ulises Ruíz, presented a bill to the executive branch to reform the national water law based on perceived dissatisfaction with the 1992 law among some water using groups. Preparing himself for a gubernatorial bid in his home state of Oaxaca, Ulises Ruíz used the water reforms as a platform to gain national visibility (Crónica Legislativa 2004). He was an unlikely champion of environmental sustainability since he is known primarily for having been governor during a repressive crackdown on social protests in Oaxaca during 2005 and 2006. The 2003 bill (1) introduced more decentralization by establishing 13 regional CONAGUA headquarters offices (Organismos de Cuenca); (2) built upon the 1992 law's creation of river basin councils and stipulated specific membership and responsibilities of the councils; and (3) defined the environment as a legitimate water user, although no rights or conditions were specified.

On 1 September 2003 (in the same month Lichtinger was ousted), the Fox administration sent the Senate its decision to veto the proposed law. President Fox objected to the more radical decentralization of CONAGUA, claiming that its proposed areas of authority were not constitutionally valid and overstepped responsibilities designated only to Hacienda (Mexico's powerful Commerce and Fiscal Ministry)(Crónica Legislativa 2004). Ulises responded to the presidential veto by organizing a series of public consultations over the next several months with water user organizations, nongovernmental organizations, agricultural producers, and water service providers to reconsider the reforms. In December 2003, Ulises and the Senatorial Water Resources Commission called for a special congressional session to consider a new set of veto-proof modifications to the LAN, which passed with 469 votes. Fox signed the newly revised LAN into law on 19 April 2004. Although the 2004 LAN required the decentralization of CONAGUA into 13 regional headquarters, the federal government later decided to maintain CONAGUA as a deconcentrated body within the SEMARNAT framework, leaving ambiguous many of the LAN's written aspects (Enciso 2007). The Organismos de Cuenca do not have financial and jurisdictional autonomy from Mexico City.

The 2004 LAN modifications should have been followed within 12 months by the adoption of a set of specific regulations to implement it. However, to date, the regulations (Reglamentaria) have been stalled in the halls of the Mexican Congress, and there appears to be little if any movement toward adopting them. Thus, today, the status of the 2004 law is ambiguous, and high-level commitment to the advances of 2004 appears uncertain.

The hotly contested 2006 presidential race was between two opposition parties, and was won by Felipe Calderón, the conservative National Action Party candidate. Thus far in his administration, Calderón has not demonstrated avid pursuit of the reformed water policy's stated goals. Calderón's environment minister, Juan Rafael Elvira Quesada, is working on reforestation to prevent flooding and on wastewater treatment in Mexico City (Deputato 2008). The former subsecretary of agriculture under Salinas, Luis Tellez, is now Minister for Communications and Transportation and has continued his focus on modernizing the water sector. One of the major initiatives focused on water is a five-year, 270 billion peso national strategy focused on public/private investment in modernizing national infrastructure, with water and environmental 
projects as two of the four priority areas identified (BBC 2008). The 2007-2012 National Water Plan emphasizes a sustainability discourse while giving priority to efficiency and productivity measures (CONAGUA 2007). The Plan reports a need to double the annual budget to address Mexico's water needs and emphasizes private investment. Mexico has been hard-hit by the global economic recession and is unlikely to allocate this scale of resources to the water sector. Calderón calls sustainable human development a central objective of his government and states that environmental sustainability is one of the Plan's guiding axes (CONAGUA 2007). The report emphasizes the role of river basin councils in facilitating public participation and promoting a new culture of water (CONAGUA 2007).

CONAGUA has proposed new changes to the LAN that would roll back some of the environmental gains of the 2004 version of the law. Due to complaints from heavy-hitting water users in agriculture and industry, CONAGUA is promoting reductions in the minimum financial penalties that apply to those who use more than their designated water allocation or who discharge untreated sewage waters.

\section{IMPACTS OF THE NEW WATER POLICY IN THE NORTHWEST STATE OF SONORA}

An overview is useful to understand how the new policy played out in two specific northwestern Mexico contexts in the border state of Sonora: irrigation districts and river basin councils (Fig. 1). Irrigation uses over $80 \%$ of water supply and is therefore a critically important sector to assess in terms of the water policy transition. River basin councils represent the principal institutional innovation of the water policy transition, reflecting the opening of the water sector to more participatory processes of planning and decision-making.

Sonora is a highly vulnerable state due to its rapidly growing urban population, intensive commercial agriculture coupled with assertive industrial and coastal development, and an arid desert climate (Ray et al. 2007). Projected climate change impacts include increased temperatures, drier conditions, reduced water supply, and more severe, prolonged droughts (IPCC 2007, Seagar et al. 2007). Sonora is the most irrigated state in Mexico and is a border state that shares a frontier with Arizona in the United States (Mexico's principal trade partner). Sonora is a crucible for a modernizing Mexico with its high concentration of foreign-owned maquiladora assembly plants, seven major commercial irrigation districts producing wheat, grapes, citrus, asparagus, and melons primarily for export to the United States and Japan, accelerated demographic growth based on domestic migration and massive tourism, and residential resort development along the Gulf of California coast. Yet despite its advantageous resource assets and insertion into the global economy, to date the achievements of water policy reforms in Sonora have been limited.

\section{Impacts in irrigation districts}

The transference of irrigation districts in Sonora represents the best claim for success in terms of the decentralization components of the water policy package. Sonoran irrigators report satisfaction with a growth in political equity represented by water user management of the district, which allows water modules (sub-district level associations) to manage their own operations, including election of leadership (rotating annually among small, communal farmers and large private producers), establishing their own quotas (beyond a districtwide base fee), and setting strategies for reinvestment of those revenues into specific projects that benefit the module (for example, installation of drip irrigation, cleaning of field-specific canals) (Wilder and Whiteford 2006, Wilder 2008). Overall, however, irrigators have experienced a net decrease in economic equity due to volatility of global agricultural markets, lack of credit, trade liberalization, elimination of subsidies, and rising input costs. Water costs alone increased in the AltarPitiquito-Caborca district by $89 \%$ for wheat, $118 \%$ for table grapes, and $186 \%$ for asparagus in the first six years after the transference (Wilder and Romero Lankao 2006); water costs in the wheat-producing Rio Yaqui irrigation district increased even faster. Small, communal producers known as ejidatarios have abandoned active production at an accelerated pace and turned more than ever to land and water leasing to private producers, resulting in de facto privatization (Luers et al. 2005, Wilder and Romero Lankao 2006, Wilder and Whiteford 2006). The water policy reforms have resulted overall in some important gains in political equity for irrigators, but these gains are overwhelmed by losses in economic equity that have resulted in non-competitive conditions even for large producers while marginal producers are struggling to hold onto their water, land, and livelihoods (Wilder 2008). 
Fig. 1. Research location: Sonora, Mexico.

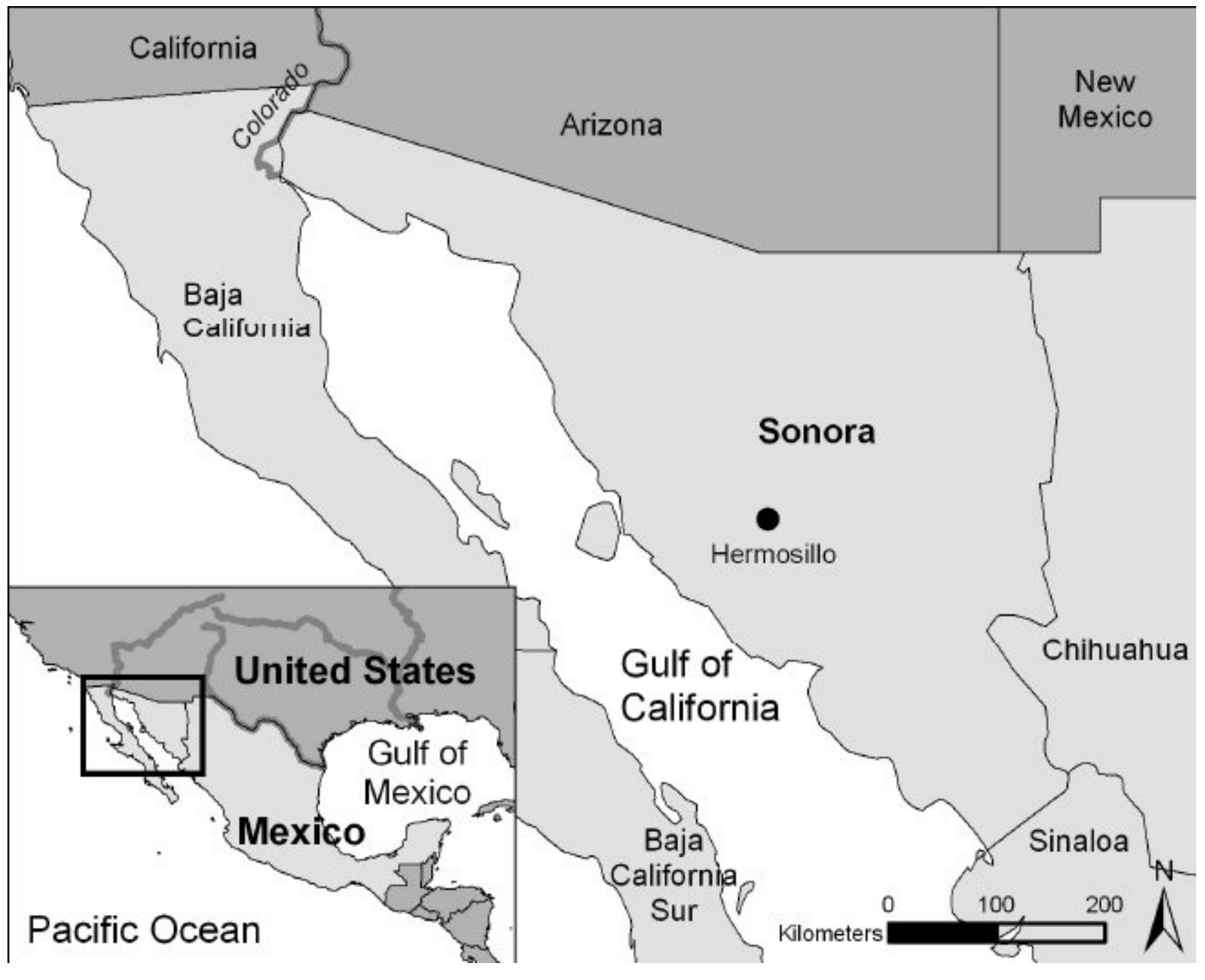

\section{Impacts in river basin councils}

The 1992 LAN required the creation of 25 river basin councils on major rivers, associated with ancillary networks of commissions and committees at the subwatershed level. Each of the major waterusing sectors, including agriculture, agro-industry, urban/domestic sector, aqua-culture and fisheries, services, and industrial uses, has an elected representative with one vote. In theory, there is a representative appointed for "ecological conservation" (SEMARNAP 1998:31). The director of CONAGUA chairs the river basin council; the governor of the state(s) containing the watershed also serves on the council. Additional representatives allowed to participate in discussions (e.g., voz) but not allowed to vote (e.g., voto) include other federal and state agencies, municipal councils, non-governmental organizations, and academics. The technical ministry of CONAGUA is allowed to participate in discussions but not vote. Participation in river basin councils is top-heavy with government representation and involves minimal citizen input. 
Sonora has three river basin councils that were officially created in 1999 and 2000 but did not have active memberships and meetings until approximately 2004. Major 2004 LAN revisions strengthened the requirements for river basin councils and citizen participation. River basin councils potentially represent a progressive step forward in using integrated water resources management strategies to resolve conflicts, conduct long-term planning, and develop more sustainable outcomes within a watershed. In reality, numerous obstacles limit the effective functioning of river basin councils, including limitations to the councils' jurisdiction and a widespread perception that they are only advisory and not significant within the decisionmaking structure. The councils' membership does not reflect local realities of water use. Irrigators use over $80 \%$ of the water supply, yet agriculture holds only one vote on the council. Government participation is disproportionately high, citizens' interests are under-represented, and there is a lack of procedural transparency and accountability (Wilder 2008). River basin councils codify citizen participation into new processes and institutions, but the potential they hold as important sites of collaborative state-citizen engagement to resolve conflicts and plan for long-term sustainability is currently unrealized.

These findings from studies of irrigation districts and river basin councils in Sonora illuminate the disconnect between the legal frameworks of 1992 and 2004 that instituted decentralized and participatory mechanisms for water governance and the limited, fragmented nature of consolidation of these reforms that has occurred in practice.

\section{ACCOUNTING FOR POLICY DYNAMICS}

\section{Discussion}

Despite the potential embodied in the 1992/2004 LAN, Mexico's transition to a new water culture has been only partial and very incomplete. While the transition to a market logic and efficiency principles has been well consolidated, the decentralization and sustainability initiatives of the law have become mired due to national political fragmentation and a lack of strong political will to allow the decentralization agenda to develop and take root. The 1992 LAN modifications were imposed in a top-down fashion by the PRIcontrolled Salinas administration, while the post-2000 experience has been one of political party alternancia (alternating political parties) typified by conflict and lack of consensus over the ultimate direction of Mexico's water policy. Political party dominance is now in a continually shifting state both across and within time and space (Wilder 2009). As Meijerink and Huitema (2010) point out, water policy transitions have a temporal aspect. In the beginning they require the alteration of policy communities that have crystallized around a policy domain. As transitions mature, they must find ways to navigate evolving political coalitions or risk capture and subversion by entrenched elites that may be reluctant to cede authority to emerging decentralized institutions. Policy change would ideally be followed by policy stability, wherein the transition itself transforms into the new stable policy. Mexico's democratic transition is launched but by no means fully consolidated (as shown in the fraud allegations after the 2006 presidential election that briefly challenged the legitimacy of Calderón's presidency). At nearly 20 years of age, Mexico's water policy appears stuck in a transitional phase.

As a result of the multiple influences of exogenous and endogenous pressures, political and economic apertures, and international prescriptions for sustainable water management, Mexico's water policy resulted in a kind of enormous soup cauldron into which all the requisite ingredients were mixed. This recipe allowed for a sustainability agenda to be grafted onto Mexico's fundamental economic agenda of making water management more efficient and productive.

Decentralization and devolution of water planning responsibilities from the federal to the local governments and to civil participants (users) has been devised in laws but has not been effectively implemented. The river basin councils have neither real power nor impact on planning, and public participation is codified but not practiced.

Transference of irrigation districts is more of a success story in institutional terms; within just eight years, $95 \%$ of major irrigation districts had been transferred to water user associations charged with managing them (CONAGUA 2007). However, decentralization resulted in a transfer of the huge financial burden of irrigation management to water users and an easing of the financial responsibility of the federal government as it retrenched. Rather than sustainability, there is greater inequity among water using sectors (e.g., private versus ejidatario farmers). 
Implementation of the decentralization agenda would potentially present challenges to the status quo - including changes in the distribution of water rights and allocations, and power trade-offs in the federal-municipal relationship. It remains to be seen whether the Mexican government will move beyond the decentralization and sustainability experiment and commit to fulfill in the future what it has begun with some degree of promise. Evidence points to an ongoing battle between the different agendas embedded within the broad water reform package, with efficiency and economic development on one side sparring with equity and sustainability on the other.

\section{Conclusion}

The Mexican case holds important lessons for the policy sciences approach. Most significant is the extent of transformation that Mexico was undergoing at the time it initiated its water policy transition. The transition in Mexico and many developing countries is about much more than water. As dramatic as the transition was, it represented only one broad policy area among many that were being modernized as the result of national economic restructuring. This complexity creates intractability or unwieldiness when it comes to applying sleek policy models that seek to reflect how policy change occurred. Mexico's experience points out the difficulties inherent in a changing political landscape where office holders, institutions, and parties are in constant flux, and policy entrepreneurs are at risk of being replaced frequently. As the galvanizing effects on advocacy coalitions fade over time as the country moves beyond the initial focusing event, it can be difficult to sustain the policy momentum.

The Mexican case highlights potential deficits in the policy sciences approach for interpreting policy change in developing countries. The framework gives prominence to the nation-state as the primary locus of policy change. In the case of Mexico and many other developing countries, structural requirements encouraged by international lending institutions and global shifts in thinking about water policy were both important factors in the transition, yet the framework does not capture this reality very adeptly. It would benefit from a more nuanced and embroidered understanding of the role of international influences - both structural and ideational - in the construction of problems and solutions in the developing world. In the same vein, the policy sciences approach assumes that water policy transitions are occurring in well consolidated democracies. In reality, the political landscape is more uneven and checkered in the developing world where the democratic transition is still being played out and taking hold unevenly across and within both time and space. The Mexican case exemplifies the nature of water policy transition as a process that occurs over time and space rather than at a particular moment. These enhancements will lend an already agile interpretive framework more flexibility to respond to water transitions in the developing democracies of the world.

Responses to this article can be read online at: http://www.ecologyandsociety.org/vol15/iss $2 /$ art22/ responses/

\section{Acknowledgments:}

The author wishes to recognize Dr. Dave Huitema and Dr. Sander Meijerink for the intellectual leadership they have demonstrated over the past three years in developing this ambitious international workshop and publishing project on international transitions in water management. I thank themfor inviting me to participate. The author gratefully acknowledges the insightful review and commentary provided by Sander Meijerink, Dave Huitema, Sara Hughes, Jennifer McKay, Helen Ingram, and Nicolas Pineda on an earlier version of this article. Some of the background material and study findings this article draws upon have been published in earlier articles (Wilder and Romero Lankao 2006, Wilder and Whiteford 2006, Wilder 2008). I extend my sincere thanks to the two anonymous reviewers who provided excellent comments on an earlier version. Finally, the author wishes to thank Edward Elgar Publishing for kindly having given permission for the use of material from D. Huitema and S. Meijerink, editors. 2009. Water policy entrepreneurs: a research companion to water transitions around the globe. Edward Elgar Publishing, Cheltenham, UK. 


\section{LITERATURE CITED}

Assetto, V. J., E. Hajba, and S. P. Mumme 2003. Democratization, decentralization, and local environmental policy capacity: Hungary and Mexico. Social Science Journal 40:249-268.

Bakker, K. J. 2004. An uncooperative commodity: privatizing water in England and Wales. Oxford University Press, Oxford, UK.

Barkin, D., and D. Klooster. 2006. Estrategias de la gestión de agua urbana. In David Barkin, editor. La Gestión de Agua Urbana en México: Retos, Debates y Bienestar. Universidad de Guadalajara, Guadalajara, Mexico.

Bauer, C. 2004. Siren song: Chilean water law as a model for international reform. Resources for the Future Press, Washington, D.C., USA.

Baumgartner, F. R., and B. D. Jones, editors. 1991. Agenda dynamics and policy subsystems. Journal of Politics 53(4):1044-1074.

Blaikie, N. 2000. Designing social research: the logic of anticipation. Polity Press, Cambridge, UK.

Blatter, J., and H. M. Ingram, editors. 2001. Reflections on water: new approaches to transboundary conflicts and cooperation. Massachusetts Institute of Technology Press, Cambridge, Massachusetts, USA.

British Broadcasting Corporation (BBC). 2008. Monitoring Latin America. February 8, 2008. Mexican President Felipe Calderon launches national infrastructure plan.

Buras, N. 1996. The water resources of Mexico: their utilization and management. Pages 229-242 in L. Randall, editor. The changing structure of Mexico: political, social, and economic prospects. M.E. Sharpe, Armonk, New York, USA.

Carabias, J., and R. Landa. 2005. Agua, medioambiente, y sociedad: hacia la gestión integral de los recursos hídricos en México. Universidad Autónoma de México, El Colegio de México, y Fundación Río Arronte, Mexico, D.F.

Castro, J. E. 2006. Water, power and citizenship: social struggle in the basin of Mexico. Palgrave Macmillan, Oxford, UK.
Comisión Nacional del Agua (CONAGUA). 1994. La transferencia de los distritos de riego en Mexico. Comisión Nacional del Agua, Mexico, D.F.

Comisión Nacional del Agua (CONAGUA). 2007. Plan nacional hídrico 2007-2012. Comisión Nacional del Agua, Mexico, D.F.

Conca, K. 2006. Governing water: contentious transnational politics and global institution building. Massachusetts Institute of Technology Press, Cambridge, Massachusetts, USA.

Cornelius, W.A. 1992. The politics and economics of reforming the ejido sector in Mexico: an overview and research agenda. LASA Forum XXIII(3):3-8.

Cornelius, W.A., T.A. Eisenstadt, and J. Hindley, editors. 1999. Subnational politics and democratization in Mexico. Center for U.S.-Mexican Studies, La Jolla, California, USA.

Crónica Legislativa. April 20, 2004. Mexico, D.F.

Cummings, R. G., V. Brajeer, J. McFarland, J. Trava, and M. El-Ashry. 1989. Waterworks: improving irrigation management in Mexican agriculture. World Resources Institute, Washington, D.C., USA.

Deputato, G. 2008. Saving Mexico. CNN report, April 1, 2008. [online] URL: http://www.cnn.com/ 2008/WORLD/americas/04/01/mexico.environment/ index.html?iref=newssearch.

Dresser, D. 1998. Post-NAFTA politics in Mexico: uneasy, uncertain, unpredictable. Pages 221-256 in C. Wise, editor. The post-NAFTA political economy: Mexico and the Western Hemisphere. Pennsylvania State University Press, University Park, Pennsylvania, USA.

Easter, W., H. Plusquellec, and A. Subramanian. 1998. Irrigation improvement strategy review: a review of bankwide experience based on selected 'new style' projects. World Bank, Washington D.C., USA.

Encisco, A. L. 2007. La Jornada newspaper. August 13, 2007. Mexico, D.F.

Gates, M. 1988. Codifying marginality: the evolution of Mexican agricultural policy and its impact on the peasantry. Journal of Latin American 
Studies 20:277-311.

Gleick, P. H., G. Wolff, E. L. Chalecki, and R. Reyes. 2002. The new economy of water: the risks and benefits of globalization and privatization of fresh water. Pacific Institute, Oakland, California, USA.

Gould, D. M. 1996. Mexico's crisis: looking back to assess the future. Pages 15-42 in L. Randall, editor. Changing structure of Mexico: political, economic and social prospects. M.E. Sharpe, Armonk, New York, USA.

Harvey, N. 1996. The reshaping of agrarian policy in Mexico. Pages 103-109 in L. Randall, editor. Changing structure of Mexico: political, economic and social prospects. M.E. Sharpe, Armonk, New York, USA.

Hinchcliffe, F., J. Thompson, J. Pretty, I. Gujit, and P. Shah. 1999. Fertile ground: the impacts of participatory watershed management. Intermediate Technology Publications Ltd., London, UK.

Hindley, J. 1999. Indigenous mobilization, development, and democratization in Guerrero: the Nahua people vs. the Tetelcingo dam. Pages 207238 in W. A. Cornelius, T. A. Eisenstadt, and J. Hindley, editors. Subnational politics and democratization in Mexico. Center for U.S.Mexican Studies, La Jolla, California, USA.

Huitema, D., and S. Meijerink. 2010. Realizing water transitions. the role of policy entrepreneurs in water policy change. Ecology and Society 15(2): 26. [online] URL: http://www.ecologyandsociety.org/vol15/ iss2/art26/.

Intergovernmental Panel on Climate Change (IPCC). 2007. Climate change (2007): the physical science basis. Contribution of Working Group I to the Fourth Assessment Report of the Intergovernmental Panel on Climate Change. Cambridge University Press, Cambridge, UK.

Kingdon, J. W. 1984. Agendas, alternatives and public policies. Second edition. Harper Collins, New York, USA.

Klooster, D. 2003. Campesinos and Mexican forest policy during the twentieth century. Latin American Research Review 38(2):94-126.
LaFranchi, H., 2000. People power grows in Mexico. Christian Science Monitor. November 8, 2000. [online] URL: http://www.csmonitor.com/20 00/1108/p6s1.html.

Lemos, M. C. 2008. Whose water is it anyway? Water management, knowledge and equity in northeast Brazil. Pages 249-270 in J. Whiteley, H. M. Ingram, and R. W. Perry, editors. Water, place, and equity. Massachusetts Institute of Technology Press, Cambridge, Massachusetts, USA.

Lemos, M. C., and A. Luna. 1999. BECC and public participation in the U.S.-Mexico border: lessons from Ambos Nogales. Journal of Borderlands Studies 14(1):43-64.

Liverman, D. M., and R. Merideth. 2002. Climate and society in the U.S. southwest: the context for a regional assessment. Climate Research 21(3):199_ 218.

Luers, A. L., R. L. Naylor, and P. A. Matson. 2005. A case study of land reform and coastal land transformation in southern Sonora, Mexico. Land Use Policy 23(4):436-447.

Meijerink, S., and D. Huitema. 2010. Policy entrepreneurs and change strategies: lessons from sixteen case studies of water transitions around the globe. Ecology and Society 15(2): 21. [online] URL: http://www.ecologyandsociety.org/vol15/iss2/art21/

Moreno, J. L. 2006. Por abajo del agua: sobreexplotación y agotamiento del acuífero de la Costa de Hermosillo, 1945-2005. El Colegio de Sonora, Hermosillo, Sonora, Mexico.

Mumme, S. P. 2000. Sustainable development and environmental decentralization on the border: some insights from Sonora. Pages 101-128 in L. Herzog, editor. Shared space: rethinking the U.S.-Mexico border environment. Center for U.S.-Mexican Studies, University of California-San Diego, La Jolla, California, USA.

Nadal, A. 2002. Corn in NAFTA: eight years after. A research report prepared for the North American Commission on Environmental Cooperation. Commission on Environmental Cooperation, May 2002, Montreal, Quebec, Canada. [online] URL: http://www.cec.org/Storage/53/4576 Corn-NAFTA en. pdf. 
Organisation for Economic Co-operation and Development (OECD). 1998. Environmental performance reviews Mexico. Organization of Economic Co-operation and Development, Paris, France. Environment and Sustainable Development 1998(3): 1-208.

Otero, G., editor. 2004. Mexico in transition: neoliberal globalism, the state and civil society. Fernwood Publishing, Nova Scotia, Canada.

Palacios Velez, E. 1997. Benefits and second generation problems: the case of Mexico. Paper presented to the International Workshop on Participatory Irrigation Management: Second Generation Problems. Cali, Colombia, 9-15 February, 1997. World Bank International Workshop on Participatory Management, Mexico, D.F.

Palacios Velez, E. 2000. Breve evaluación del proceso de la transferencia de los distritos de riego en Mexico. Pages 121-130 in E. Palacios Velez and E. Espinosa de Leon, editors. Procesos de Transferencia y Gestión, Mesa 1. Comisión Nacional del Agua, Mexico, D.F. 1.

Perez Prado, L. N. 2003. Mexico's irrigation management transfer program: notes for a policy research agenda. Journal of Environment \& Development 12(4):373-388.

Pineda Pablos, N. 1999. Urban water policy in Mexico: municipalization and privatization of water services. Dissertation. Department of Latin American Studies, University of Texas, Austin, Texas, USA.

Pineda Pablos, N. 2004. Hermosillo y su agua. El Colegio de Sonora, Hermosillo, Sonora, Mexico.

Pineda Pablos, N., editor. 2006. La búsqueda de la tarifa justa:el cobro de los servicios de agua potable y alcantarillado en Mexico. El Colegio de Sonora, Hermosillo, Sonora, Mexico.

Pineda Pablos, N. and E. R. Camou. 2007a. De las buenas intenciones a las cuentas claras: Planeación, desempeño, y rendición de cuentas en seis municipios de Sonora. El Colegio de Sonora, Hermosillo, Sonora, Mexico.

Pineda Pablos, N., A. Browning-Aiken, and M.
Wilder. 2007b. Equilibrio de bajo nivel y manejo urbano del agua en Cananea, Sonora. Frontera Norte 19(37)(enero-junio):143-172.

Preston, J., and S. Dillon. 2004. Opening Mexico: the making of a democracy. Farrar, Straus and Giroux, New York, USA.

Ray, A. J., G. M. Garfin, M. Wilder, M. VásquezLeón, M. Lenart, and A. C. Comrie. 2007. Applications of monsoon research: opportunities to inform decision making and reduce regional vulnerability. Journal of Climate 20(9): 1608-1627.

Sabatier, P. A. 1993. Policy change over a decade or more. Pages 13-40 in P. A. Sabatier and H. C. Jenkins-Smith, editors. Policy change and learning: an advocacy coalition approach. Westview Press, Boulder, Colorado, USA.

Santa-Cruz, A. 2007. Contested compliance in a liberal normative structure: the Western Hemisphere idea and the monitoring of Mexican elections. Paper presented at International Studies Association 2007 Annual Meeting, Chicago, Illinois, USA, Feb. 28March 3.

Seagar, R., M. Ting, I. Held, Y. Kushnir, J. Lu, G. Vecchi, H. Huang, N. Harnik, A. Leetmaa, N. Chau, L. Cuihua, J. Velez, and N. Naik. 2007. Model projections of an imminent transition to a more arid climate in southwestern North America. Science 316(5828):1181-1184.

Secretaria de Medio Ambiente, Recursos Naturales, y Pesca (SEMARNAP). 1998. Los consejos de cuenca en Mexico: definiciones y alcances. Unidad de Programas Rurales de Participacion Social, Coordinacion de Consejos de Cuenca. Comisión Nacional del Agua, Mexico, D.F.

Tellez, L., editor. 1993. Nueva legislación de tierras, bosques y aguas. Mexico, D.F.: Fondo de Cultura Económica.

Torregrosa, M. L. 1995. Aspectos sociales de los procesos de modernización y transferencia de los distritos de riego: un contexto para el planteamienta de un problema. Paper presented at Jornada sobre el Agua, Hermosillo, Sonora, Mexico.

Valdés-Ugalde, F. 1996. The changing relationship between the state and the economy in Mexico. Pages 55-62 in L. Randall, editor. The changing structure 
of Mexico: political, social, and economic prospects. M.E. Sharpe, Armonk, New York, USA.

Varady, R. G., K. Meehan, J. Rodda, E. McGovern, and M. Iles-Shih. 2008. Strengthening global water initiatives. Environment March/April 2008:20-41.

Vera, R. 2003. Lichtinger: ajuste de cuentas. Proceso. September 8, 2003.

Whiteford, S., and R. Melville, editors. 2002. Protecting a sacred gift: water and social change in Mexico. Center for U.S.-Mexican Studies, University of California Press, La Jolla, California, USA.

Wilder, M. 2008. Equity and water in Mexico's changing institutional landscape. Pages 95-116 in J. M. Whiteley, H. Ingram, and R. Warren Perry, editors. Water, place, and equity. Massachusetts Institute of Technology Press, Cambridge, Massachusetts, USA.

Wilder, M. 2009. Political and economic apertures and the shifting state-citizen relationship: reforming Mexico's national water policy. Pages 79-96 in D. Huitema and S. Meijerink, editors. Water policy entrepreneurs: a research companion to water transitions around the globe. Edward Elgar Publishing, Cheltenham, UK.

Wilder, M., and P. Romero Lankao. 2006. Paradoxes of decentralization: neoliberal reforms and water institutions in Mexico. World Development 34(11):1977-1995.

Wilder, M., and S. Whiteford. 2006. Flowing uphill towards money: groundwater and free trade in northern Mexico's Ejido sector. Pages 341-358 in L. Randall, editor. The changing structure of Mexico: political, economic and social prospects. Second edition. M.E. Sharpe, Armonk, New York, USA.

Yates, P. L. 1981. Mexico's agricultural dilemma. University of Arizona Press, Tucson, Arizona, USA.
[1] This research was supported by an InterAmerican Grassroots Development Dissertation Fieldwork Fellowship; by the National Oceanic and Atmospheric Administration (NOAA) Office of Global Programs grant, Use of Climate Information by Water Managers and Other Stakeholders in Two GCIP/GAPP Watersheds in Arizona/Sonora and Oklahoma (2003-2006); and by NOAA's Climate Assessment of the Southwest (CLIMAS), Variability, Social Vulnerability, and Public Policy in the Southwestern United States (2002-2007). The author expresses gratitude to Edward Elgar Publishing for allowing me to use some material based on my chapter in D. Huitema and S. Meijerlink. 2009. Water policy entrepreneurs: a research companion to water transitions around the globe. Cheltenham, UK.

[2] The new National Water Law (Ley de Aguas Nacionales) was published in the Diario Oficial (Mexico's Congressional Record) on 1 December 1992 and became effective the following day. The LAN was the regulatory statute (reglamentaria) to Article 27 of the Constitution governing national waters (Tellez 1993:104). The regulation implementing the law was adopted on 12 January 1994. It replaced the former national water law, the Federal Law of Waters (Ley Federal de Aguas), that had been in effect since 1972 (Vargas et al. 1994:9), and which in its turn had supplanted the earlier water legislation, Law of National Property Waters (Ley de Aguas de Propiedad Nacional) dating to 1936.

[3] The OECD Environmental Performance Review for Mexico (OECD 1998: 26-27) attests to the importance of the "comprehensive approach" Mexico has followed in assembling within one ministry the responsibilities for environment, forestry, soil, fisheries and aquaculture, stating that it "has developed new and far-reaching strategies, policies and programmes that are now in the early stage of implementation". The report also praises the broad range of legislative and regulatory advancements put into place during the early period of SEMARNAP (later SEMARNAT) environment ministry.

${ }^{[4]}$ I owe this insight to an astute anonymous reviewer of an earlier version of this article. 